\title{
Metaphoric Topicality in Femi Osofisan's Drama
}

\author{
Clement O. Ajidahun \\ Adekunle Ajasin University, Akungba Akoko, Nigeria \\ Email: jideajidahun@yahoo.co.uk,jideajidahun@gmail.com \\ Received November $8^{\text {th }}, 2012$; revised December 11 $1^{\text {th }}, 2012$; accepted January $9^{\text {th }}, 2013$
}

\begin{abstract}
This paper examines the functional and the significant role of metaphors in literary works. It discusses the centrality of metaphors as a dominant literary device consciously deployed by Femi Osofisan to project the theme of oppression, dehumanization, social injustice and poverty in his plays. The paper focuses on the use of animal and predatory metaphors in Osofisan's plays to launch an offensive literary attack on the rich and the ruling elite in the society who use their privileged positions to brazenly oppress and brutalize the poor and the downtrodden. The paper, on the other hand, examines the appropriate use of animal metaphors to enlighten and educate the poor on their precarious condition as preys in the hands of the carnivorous ruling class. Finally, the paper discusses the settings and the titles of Osofisan's plays, the quest motif and the traditional modes as metaphors for oppression.
\end{abstract}

Keywords: Osofisan; Metaphor; Language; Drama

\section{Introduction}

Metaphor is indisputably a linguistic and literary tool employed by the writer to communicative effectively his message to his audience. Writers, irrespective of their genres, find this figure of speech compelling and indispensable in their literary works. And since the emergence of linguistics, there has been a deliberate and consistent attempt to provide a linguistic foundation for the literary effects of figures of speech in literary works. This has also attracted literary stylistics. Commenting on the significance of metaphor, MacCormac (1972, p. 3) is of the view that literature without metaphor would become less imaginative and poetry would be so impaired as to become dull and perhaps even trite. Writers and critics have rarely denied the utility and attractiveness of metaphor for their trade.

Critical studies on metaphor in literature cannot be effectively done without the employment of the appropriate linguistic tools. According to Semino and Steen (2008, p. 232), "we believe that metaphor in literature needs to be studied by combining literary approaches with a combination of discourse analytical, corpus-linguistic and psycholinguistic techniques."

According to the classical view on the literal language theory, which can be traced to Aristotle, metaphor is seen as extraneous to language and therefore it requires a special interpretation. To the classical school of thought, metaphor is anomalous. For instance, according to Levin (1977) as reported by Finch (2000, p. 170), it is abnormal to say The stone died because the features of stone and die are incompatible. Meaning and interpretation, can therefore, be decoded through translation in order to find "a non-metaphorical, literal equivalent."

However, the romantic school of thought according to Finch (2000, p. 171) "views metaphor not as an anomaly requiring special methods of interpretation, but as an integral part of language and thought...all language is essentially metaphorical." This is in tandem with the position of the cognitive semanticists. The works of Lakoff and Johnson (1980) amply discuss this concept using the structural, orientational and ontological types of metaphor as illustrations.

Femi Osofisan differs from the classical school of thought on the role of metaphor in literature. He is perfectly in agreement with the romantic view that makes no difference between the figurative and non-figurative language. Osofisan uses metaphors consciously as a normal linguistic apparatus to make critical statements of facts that he considers crucial and to provoke and arouse the consciousness of our leaders to the worrisome living condition of the downtrodden in the society. This paper is, therefore, an examination of the dominance of the use of metaphors in the drama of Femi Osofisan.

\section{Textual Analysis}

Osofisan uses animal and predatory metaphors virtually in all his plays to portray the unpleasant relationship between the rich and the poor in the society. The rich and the ruling elite class who are portrayed as rapacious, ravenous, inhuman, barbarous, bestial and fiendish use their privileged positions to maltreat, subdue, repress and oppress the poor with ferocious brutality. The poor, in the hands of the rich, are completely dehumanized through their draconian policies and authoritarian tendencies. They rule with infernal authority. Osofisan thus finds appropriate animal and predatory metaphors to project these bestial manifestations in the ruling class.

Similarly, the poor are depicted as preys in the hands of the rich and as pawns in the hands of the gods who kill them for their meat at will. The poor are like flies to wanton boys who trample upon them pitilessly. The poor are always at the mercy of the rich completely depending on them for survival. The playwright describes them with appropriate metaphors to depict their socio-economic fragility, financial insolvency, physical defenselessness and vulnerability. It is only when we look at this predatory relationship between the rich and the poor that our radical impulse and revolutionary consciousness can be aroused. Some examples of these metaphors are juxtaposed below: 


\begin{tabular}{|c|c|c|}
\hline Oppressors (the rich) & Oppressed (the poor) & Source \\
\hline Elephant & Antelope & The Chattering and the Song, 45 \\
\hline Lion ( Abiodun) & Toad (Latoye) & The Chattering and the Song, 38 \\
\hline Buffalo & Antelope & The Chattering and the Song, 45 \\
\hline Hunting Dog & Sacrificial ram & Once Upon Four Robbers, 67 \\
\hline Elephant & Mosquito & Morountodun, 18 \\
\hline Hawk (Sontri) & Hen (Yajin) & The Chattering and the Song, 2 \\
\hline Lion & Dogs & Red is the Freedom Road, 125, 128. \\
\hline Crabs, Scorpions & Stray dogs, maggots & No More the Wasted Breed, 93, 100 \\
\hline Hen & Cockroach & Midnight Hotel, 61 \\
\hline Hyena (Adigun) & Antelope (Akanbi) & Farewell to a Cannibal Rage, 9 \\
\hline Locust & Grasshopper & The Oriki of a Grasshopper, 27 \\
\hline Monkey & Goat & Altine's Wrath \\
\hline Rodent & Rat & Another Raft, 27 \\
\hline Sharks & Fishes & Another Raft, 69. \\
\hline Cannibals & Toad & Birthdays Are Not For Dying, 12, 20 \\
\hline Cat & Rat & Aringindin and the Nightwatchmen, 33 \\
\hline Vultures, Jackals, Dogs, Cat & Cockerel, rat & Nkrumah-Ni... Africa, Ni, 47, 116, 130, 150, 153. \\
\hline Jackals & Pests & Reel, Rwanda, 181, 191 \\
\hline Wolves & Jackals & The Inspector and the Hero, 97 \\
\hline Hawk & Hen & Yungba-Yungba and the Dance Contest, 72 \\
\hline Buffalo & Antelope & Yungba-Yungba and the Dance Contest, 32 \\
\hline Monster Bilisi & Big Cock, fish & Twingle-Twangle, A Twynning Tayle, 18 \\
\hline Lion & Fat pigeon, fish & Tegonni, An African Antigone,38, 108 \\
\hline Vultures & Goats, Dogs & Tegonni, An African Antigone, 38, 57 \\
\hline
\end{tabular}

The use of these metaphors gives a concrete image and the predatory relationship between the rich and the poor. While the rich, who are the lions, the vultures, the hawks, the sharks, the wolves, the jackals in the society, devour all the resources of the land, the poor antelopes, goats, mosquitoes, rats and cockroaches are left with the crumbs or even nothing.

Often, they go on starving. The metaphors are apt therefore as the stark reality of the oppression and the exploitation of the people to stir the audience's psyche. The audience cannot but be sympathetic to the cause of the downtrodden. Alafin Abiodun in The Chattering and the Song (1976) is confronted with the reality of his tyranny by Latoye when he says:

Yes, Abiodun, yes, Olori! Sango eats, Ogun eats, and so do the ebora of the forest! But in your reign Abiodun, the elephant eats, and nothing remains for the antelope! The buffalo drinks, and there is drought in the land! Soldiers, seize him! He is ripe for eating! (45)

In The Chattering and the Song (1976), Sontri, because of his oppressive, repressive, harsh and cruel dispositions, he is described as a hawk, the bird of prey, while Yajin his victim is portrayed as hen. The relationship between a hawk and a hen is predatory. The hawk feeds on the chicks and thereby deprives the hen of its natural process of procreation.

In Atine's Wrath (1986), the playwright uses monkey and goat as animal metaphors for the rich and the poor respectively. In the play, Lawal who is a Permanent Secretary in a government ministry represents the rich and the elite, oppresses his wife Altine who typifies the poor and the downtrodden. Lawal exploits the peasant farmers like Onene and Audu. The poor are described as goats meant as both beasts of burden and as meat for the playful, laissez-faire and lazy monkey. Goats as domestic animals in African environment are seen as irritants that must be chained, beaten to submission or butchered for meat This is, therefore, the experience of the poor in the hands of the rich in Nigeria. The use of predatory metaphors here to depict the oppression and the exploitation of the poor by the ruling class in the Nigerian society is appropriate.

In Another Raft (1988), Chief Ekuroola, Chief Orousi and Prince Lanusen who symbolize the rich and the elites are described as sharks, while Oge, Waje and Reore the poor are depicted as fish. The sharks are after the fishes in the sea to feed on. The sharks and the fishes are again predatory metaphors to describe the precarious rapacious relationship between the rich and the poor.

Besides, the settings of Osofisan's plays are in themselves metaphors for suffering, difficulties and poverty. For instance, the Iloto hill of Farewell to a Cannibal Rage (1986) is a metaphor for difficulties, hardship and destitution. The crossroads of Esu and the Vagabond Minstrels (1991) is a metaphor for anxiety, apprehension and despair.

The dark, bare stage of Nkrumah-Ni... Africa-Ni (1991), the dark empty stage of Another Raft (1989) and the bare sitting room of A Restless Run of Locusts are metaphors for squalor, emptiness, gloominess, murkiness, poverty and suffering. The 
Babalawo's shed in Twingle-Twangle: A Twynning Tayle (1995) is a metaphor for wretchedness, poverty and vulnerability. Others are the public square of Twingle-Twangle, A Twynning Tayle (1995; the public square of Tegonni: An African Antigone (1999); the Beachside of No More the Wasted Breed; the hotel of Midnight Hotel (1986) and the open space showing the temporary tents of the old markets built of wooden and bamboo stakes, and straw roofs, in which the women are being kept in Women of $O w u$ (2009). They depict the struggling, poverty, depravity and the decadence that are often associated with the poor and the downtrodden.

Even the D. O's office in Tegonni: An African Antigone (1999), which is up the hill side gives one the image of toughness, tyranny and oppression. The market of Once upon Four Robbers (1980), Fires Burn and Die Hard (1990) and YungbaYungba and the Dance Contest (1993) represents the world in African metaphysics where everybody comes to struggle, travail and trade. While some succeed, some fail depending on several factors like destiny, perseverance, wisdom and so on. As the market women return home at the end of each market day, eventually, everybody will one day return to the ancestors at the end of his or her journey to this world which the market represents.

Osofisan also uses quest motif to symbolize man's struggles and travails in the world. Sango in Many Colours Make the Thunder King (1999) is in search of how he can excel and surpass his father's achievements and be a man. In the course of his search, he runs into trouble. He later misuses his position. Taye and Kehinde in Twingle-Twangle, A Twynning Tayle (1995) embark on a journey of life which symbolizes man's struggles, and the need for man to have patience and perseverance. Through the metaphor of the motif, Osofisan shows that man in his search for happiness, hope and achievement and fulfilment will experience difficulties in life which could involve oppression. All that he needs are patience and perseverance.

Even the titles of some of his plays are symbolic of the sufferings of the poor masses. For instance, A Restless Run of Locusts (1975) shows the hardships and the devastation the politicians and the ruling class brings upon the land through their careless display of power and lust for money and position.

Also, the title of the play The Chattering and the Song (1976) is Sontri's belief that the chirruping of birds is called a song while the weaverbirds' chatter in chorus is also called a song. The title will then become a symbol of liberty and freedom which birds generally experience but which is elusive to man because of the oppressive apparatuses in the society which are perpetrated by the ruling class and the wealthy capitalists.

Other titles like Once upon Four Robbers (1980), Fires Burn and Die Hard (1990), No More the Wasted Breed (1983), Red Is the Freedom Road (1983), Farewell to a Cannibal Rage (1986) and Esu and the Vagabond Minstrels (1991) are symbolic of poverty, deprivation, suffering and oppression. "Robbers" are a nuisance and outcasts in the society. Fires devour and consume. "Red" is a symbol of danger. The danger in the text could mean that any attempt made by the poor to liberate themselves from the hands of the oppressors could be very bloody. Truly, the attempt made by Akanji in the text ends in tragedy both for the oppressed and for the oppressors.

"Cannibal Rage" symbolizes rivalry, strive and absence of peace which the poor always experience in the hands of the Adiguns of the society. "Vagabonds" stands for the level of dehumanization and deprivation the society has created for the downtrodden. For instance, the vagabonds in Esu and the Vagabond Minstrels (1991) refer to themselves in powerful metaphors of poverty as "living corpses" and "furnace of rioting embers" (p. 6) while the victims of Rwandan war in Reel, Rwanda (1999) are referred to as "floating corpses" (p. 179) and "rotting corpses" (p. 187).

Osofisan also uses songs, dances, riddles, parables and games as metaphors for instance, the "Dance of the Crawling Things" and "The Farmers" Anthem" in The Chattering and the Song (1976) indict the bestial nature of the ruling class and call for the unity of the masses in the dethronement of oppression and exploitation. "The story of Stomach and the Limbs" in Yungba-Yungba and the Dance Contest, (1993) "The Song of the Market Women" in Once upon Four Robbers (1980), "The story of Simbi and the Stranger" in Farewell to a Cannibal Rage and "The riddles of Ant" in Many Colours Make the Thunder-King (1999) portray the awful condition of the poor caused by the recklessness and misuse of power by the capitalists in the society. Games, like the card game played by Leje and Mokan in The Chattering and the Song (1976), are used as a dramatic metaphor and a transistor device to re-enact the past and project the future.

\section{Conclusion}

Metaphor, therefore, to Osofisan is a formidable and indispensable literary apparatus for lampooning and chastising the oppressive structures in the society and for enlightening and exposing the true conditions of the masses with a view to provoking them to stand in unity for their liberty and total emancipation. Metaphors have therefore been adequately deployed by the playwright to strengthen the theme of oppression that is prevalent in his plays.

\section{REFERENCES}

Finch, G. (2000). Linguistic terms and concepts. New York: Palgrave Macmillan.

Lakoff, G., \& Johnson, M. (1980). Metaphors we live by. Chicago, IL: University of Chicago Press.

Levin, S. (1977). The Semantics of Metaphor. Baltimore, MD: Johns Hopkins University Press.

Osofisan, F. (1994). The Album Of the Midnight Blackout. Ibadan: Ibadan UP.

Osofisan, F. (1989). Another raft. Lagos: Malthouse Press.

Osofisan, F. (1992). Aringindin and the Nightwatchmen. Ibadan: Heinemann.

Osofisan, F. (1990). Birthdays are not for dying and other plays: The inspector and the hero, and fires burn and die hard. Lagos: Malthouse Press.

Osofisan, F. (1976). The chattering and the song. Ibadan: UP.

Osofisan, F. (1991). Esu and the vagabond minstrels. Ibadan: New Horn Press.

Osofisan, F. (1986). Farewell to a cannibal rage. Ibadan: Evans Publishers.

Osofisan, F. (1986). Midnight hotel. Ibadan: Evans Publishers.

Osofisan, F. (1983). Morountodun and other plays; No more the wasted breed and red is the freedom road. Lagos: Longman.

Osofisan, F. (1980). Once upon four robbers. Ibadan: Heinemann.

Osofisan, F. (1999). Recent outings II two plays: Nkrumah-ni...Africa ni! and reel, rwanda! Ibadan: Opon Ifa Readers.

Osofisan, F. (1999). Recent outings I two plays: Tegonni, an african antigone, and many colours make the thunder-king. Ibadan: Opon Ifa Readers. 
Osofisan, F. (1975). A restless run of locusts. Ibadan: Onibonoje Press. Osofisan, F. (1995). Twingle-Twangle: A twynning tayle. Lagos: Longman.

Osofisan, F. (1986). Two one-act plays: The oriki of a grasshopper and Altine's wrath. Ibadan: New Horn Press.

Osofisan, F. (2009). Women of Owu. Ibadan: University Press Plc.

Osofisan, F. (1993). Yungba Yungba and the dance contest. Ibadan:
Heinemann.

MacCormac, E. R. (1972). Metaphor and literature. Journal of Aesthetic Education, 6, 57-70. doi:10.2307/3331393

Semino, E., \& Steen, G. (2008). Metaphor in literature. In R. W. Gibbs Jr. (Ed.), The Cambridge handbook of metaphor and thought. Cambridge: Cambridge University Press, 232-235.

doi:10.1017/CBO9780511816802.015 